pituitary gland during pregnancy. The biochemical features of grass tetany and 'Utrecht abnormality of milk', which results in curdling of the milk of apparently healthy cows during transportation of their milk or when it is boiled, were also discussed. The second lecture, entitled "Gastro-intestinsl Autointoxication in Cattle and Horses", included a discussion of Dutch methods of treating acetonæmia. Much attention has been recently given to treatment with potassium chlorate, which may be beneficial if the liver is not seriously damaged. Lactate therapy, practised since 1942, has also given good results. The third lecture dealt with the complex subject of real and conditioned deficiencies of trace elements. Evidence has been obtained that in many cases increased motility of the intestine, due to causes independent of the amounts of trace elements in the food, such as the intake of protein and other components of rank spring grass, nematode infestations and paratuberculosis, may cause decreased absorption of trace elements. Intravenous administration of radioactive copper salts had shown that the liver plays an important part in the accumulation of copper. No relation between grass tetany of Dutch cattle and the intake of manganese could be obtained, but significant differences between the manganese content of grass from different soils were noted, the more alkaline soils containing the least manganese.

\section{Earthquakes Registered in New Zealand during February 1948}

Six strong earthquakes were registered by the seismographs in New Zealand during February 1948. They were on February $9(2), 10,14,16$ and 23 , that on February 9 being felt in Anatolia (Turkey). In addition, eighteen local earthquakes were felt in some place in New Zealand during the month. The greatest intensity of any one of these was scale 5 (Modified Mercalli intensity scale) in the Cook Strait region of both islands on February 4, the epicentre being near lat. $40 \cdot 95^{\circ} \mathrm{S}$., long. $173 \cdot 6^{\circ} \mathrm{E}$., and depth of focus approximately $50 \mathrm{~km}$. Earthquakes with scale 4 intensity occurred on February 9 in the Wellington and Wairarapa Regions, on February 18 in the Uruwera District and on February 29 near Lake Coleridge.

\section{Union Catalogue of German Books and Periodicals}

OwING to the scarcity of German books and periodicals published since the beginning of the Second World War, the Foreign Office has requested the National Central Library to compile a union catalogue of such of these publications as have reached the United Kingdom. A circular has been issued asking libraries and other institutions to co-operate by amending a check-list indicating their holdings. Anyone who is willing to assist but has not seen the circular should write to the National Central Library (German Union Catalogue), Malet Place, W.C.1.

\section{Geophysics at Hamburg}

AT Hamburg, the University Meteorological Institute, the Centre for Earthquake Research and the University Institute for Oceanography have been amalgamated to form the Geophysical Institute of the University of Hamburg. The address is now Hamburg 13, Rothenbaumchaussee 33. The new Institute is working under difficulties, and would welcome exchanges of geophysical publications.

\section{Society for the Bibliography of Natural History}

AT a general meeting of the Society for the Bibliography of Natural History held at the Brifish Museum (Natural History) on February 28 the following officers were elected: President, Dr. J. Ramsbottom; Secretary and Treasurer, Mr. A. C. Townsend, British Museum (Natural History), Cromwell Road, London, S.W.7; Committee, Prof. F. Balfour Browne and Messrs. J. Delacour, W. N. Edwards, F. J. Griffin, Francis Hemming and C. Kirke Swann. It is hoped to revive the activities of the Society, which was founded in 1936, and it was announced at the meeting that a further part of the second volume of the Society's Journal is in the press. This consists of a bibliography of whaling by Dr. J. Travis Jenkins. The last part of the Journal to be published was Vol. 2, Part 3, issued in April 1946.

\section{Research on Nematology}

The Institute of Agricultural Parasitology, Winches Farm, 395 Hatfield Road, St. Albans, Herts, formally ceased to exist as such on September 30, 1947. So far as plant-eelworm work is concerned, its place has been taken by a new Nematology Department of Rothamsted Experimental Station with the following scientific staff: Dr. T. Goodey (head of the Depart. ment), Dr. B. G. Peters, Dr. Mary T. Franklin, Mr. D. W. Fenwick, and Mr. J. B. Goodey. From June 30 this Department will be housed at Rothamsted Experimental Station, Harpenden, Herts. Winches Farm is continuing as a field station of the London School of Hygiene and Tropical Medicine, with Mr. J. W. G. Leiper as administrative officer.

\section{University of Leeds}

The University of Leeds has received a further grant of $£ 10,000$ from the Worshipful Company of Clothworkers, making a total grant of $£ 30,000$ to meet the capital cost of the extension of the Textile Industries Department now in course of construction. The British Hat and Allied Feltmakers' Research Association has given $£ 1,000$ for research in the same Department.

The following appointments have been made: Dr. F. Henriques, lecturer in social anthropology; $\mathrm{Mr}$. A. N. Greenwood, lecturer in electrical engineering; Mr. C. Kisby, lecturer in textile design.

\section{Commonwealth Fund Fellowships}

THE list of awards of Commonwealth Fund Fellowships tenable by British graduates in American universities for one year, beginning September 1948, includes the following: E. R. Andrew, Christ's College and Pembroke College, Cambridge, to Harvard University, in physics; J. R. G. Bradfield, Trinity College, Cambridge, to the College of Medicine, University of Illinois, in biology; S. L. Bragg, Trinity College, Cambridge, to the Massachusetts Institute of Technology, in engineering; Dr. Archibald Brown, University of Glasgow and Trinity College, Cambridge, to Yerkes Observatory, University of Chicago, in astronomy; Dr. C. A. Bunton, University College, University of London, to the College of Physicians and Surgeons, Columbia University, in biochemistry; Dr. G. M. Carstairs, University of Edinburgh, to Cornell University, in cultural anthropology; R. B. Hunter, University of Edinburgh, to Johns Hopkins School of Medicine, in medicine ; Dr. D. O. Jordan, University of London and University College, Nottingham, to Princeton 